\title{
Some studies on bovine ephemeral fever in cattle and buffaloes in Egypt
}

\author{
K. M. Ammar ${ }^{1}$, M. S. Wassel ${ }^{2}$, Nirmeen G. Shafiek ${ }^{2}$ \\ ${ }^{1}$ Deartment of Animal Medicine, Faculty Veterinary Medicine Kafre El-Sheikh, \\ Tanta University., Kafre El-Sheikh, Egypt \\ ${ }^{2}$ Central Laboratory for Evaluation of Vet. Biologics, Abbasia, Cairo, Egypt.
}

\begin{abstract}
During summer 2004, an outbreak of bovine ephemeral fever (BEF) had been spread among cattle as well as buffaloes in Egypt. The most striking clinical signs in cattle were fever of short duration, depression, stiffness, lameness and sometime recumbency. Young calves, unfattened bulls and dry, lean non-pregnant cows showed only mild signs while fattened calves, mature heavy bulls and high-producing dairy cows and cows at the late stages of pregnancy were severely affected and signs persisted longer. Deaths and other complications accompanied the disease such as subcutaneous emphysema was not recorded in these outbreaks. In buffaloes, the clinical signs were mild and less severe compared with that of cattle. Serological examination of paired serum samples collected from the diseased animals using serum neutralization test revealed rising of the neutralizing antibody titers for BEF virus after 3 weeks from the onset of clinical signs. Blood picture and biochemical analysis of sera of 6 diseased animals, showed anemia represented by significant decrease in RBCS, PCV\% and $\mathrm{Hb}$ content. The leukogram showed neutrophihia and lymphopenia with normal leukocytic count. There was rise in plasma fibrinogen with drop in calcium and phosphorus values. All of these parameters were more or less improved three weeks post-recovery. Good nursing care with early treatment with non-steroid anti-inflammatory drug (Phenylbutazone) or administration of calcium borogluconate of lame or recumbent animals lead to rapid and prompt recovery.
\end{abstract}

Bovine ephemeral fever (BEF, three days sickness, stiff sicknes, bovine epizootic fever) is an arhropod-borne viral disease of cattle and water buffaloes caused by an Ephemerovirus of the family Rhabdoviridae characterized by fever of short duration, depression, respiratory signs, stiffness, lameness and sometime paralysis (Nadi and Negi, 1999 and Kahrs, 2001). The disease occurs mainly in Austeralia, Africa and Asia (Burgess, 1971). Great economic losses were attributed to the disease such as fall in milk production by $50-80 \%$ and most cows could not return to pre-illness production level, decrease of body weight of the prime animals up to $20-30 \%$ and disruption of stock movement and market (St. George, 1998). In addition, it may be followed by various complications such as pneumonia, mastitis, hindquarter paralysis, pulmonary and subcutaneous emphysema, abortion and temporary sterility in bulls (Hill and Schultz, 1977; Theodoridis et al., 1973 and Sharma, 1992).

In Egypt, the disease was firstly described clinically by (Rabagliati, 1924). Since this time, no publication about the occurrence of the disease could be traced untilll summer 1991, where an outbreak of the disease had been occurred (Hassan et al., 1991). After this, several waves of the disease were reported in summer 1994, 2000 and 2001 (Banoub, 1994; Zaghawa et. al., 2000 and Soad et. al., 2001) and more recently in summer 2004. Reviewing the literature concurring the disease in Egypt, it was clear that researches were directed to investigate the disease among cattle with no or little attention to buffaloes. Therefore the aim of the 
present study was to through the light on some clinical aspects of the disease among individually bred cattle and buffaloes in Egypt as well as to study some hematological and biochemical changes accompanying the disease. In addition, treatment trial of severely affected cases of the disease was carried out.

\section{Material and Methods}

Animals. A total of 1785 individually bred animals (1248 cattle and 537 buffaloes) of different ages and sex from different localities at EL-Menofia province, Egypt, were clinically examined according to (Rosenberger, 1990). Some of these animals had signs suggestive for bovine ephemeral fever.

Samples. For serological examination, paired serum samples were collected from the animals showing sings of bovine ephemeral fever, the first was early during the rise of body temperature and the second, after recovery by 3 weeks to estimate the neutralizing antibodies titers against bovine ephemeral fever virus using virus neutralization test according to (Cabery and Lee, 1966). The antibody titers were calculated as the reciprocal of the final serum dilution, which neutralized and inhibited the CPE of the used virus according to (Singh et al., 1967). For hematological examination and biochemical assay, Paired whole blood samples were collected from six diseased cows, the first during the early rise of temperature and the other, 3 weeks later. Each blood sample was divided into two portions. The first was collected on EDTA as anticoagulant for hematological examination (Coles, 1986). The second portion was collected without anticoagulant for biochemical assay of some elements as calcium and phosphorus by using special kits (Tietz, 1986).

Treatment trials. The diseased animals were put in shaded place with cold application especially over the head and on lower extremities to reduce the high body temperature. Administration of non-steroid anti-inflammatory drug, Phenyl butazone (Buta-Fenil, AM Trading, Lab. Tornel, Mexico) at a dosage rate 5-20 $\mathrm{ml} /$ animals by intramuscular route in the early stages of the disease, was done. In lame or recumbent animals, calcium borogloconate (CaD-Mag, Pfizer, Egypt) at a dosage rate $500 \mathrm{ml} /$ animals injected slowly by intravenous route was administrated.

Statistical analysis. The obtained data were statistically analyzed to determine mean $\pm \mathrm{SE}$ according to (Selvin, 1996).

\section{Results and Discussion}

Bovine ephemeral fever is an acute, insecttransmitted viral disease affecting cattle and water buffalo in a variety of ecosystems in Australia and many parts of Africa, Asia and the Middle East. Ephemeral means transient or short-lived. The name fits the sudden onset and short course of the disease. Despite extensive study, BEF remains an epidemiological enigma (Kahrs, 2001).

In this study, clinical examination of the investigated animals revealed those 397 (31.81\%) cattle and 35 (6.52\%) buffalo showed clinical sings referred to bovine ephemeral fever (Table. 1). In cattle, the clinical sings were varying among affected animals. Some of them have only a transient fever with few other overt clinical signs such as lameness in one or more legs, inappetence, slight shivering, slight stiffness, excess salivation, nasal and / or lachrymal discharge with disappearance of all of these signs within 12-24 hours (mild form). But the most affected cattle display the most severe from of the disease which characterized by sudden onset of high fever $\left(40.5-41.5^{\circ} \mathrm{C}\right)$, depression, complete anorexia, hurried respiration which is usually accompanied by dyspnoea and respiratory rales, rapid pulse, muscle shivering, ruminal stasis, salivation, nasal and lachrymal discharge, stiffness, lameness in one or more legs, enlargement of lymph nodes and subcutaneous edema especially around the joint. They may assume a sitting 
Table (1): Results of clinical examination.

\begin{tabular}{lccc}
\hline \multirow{2}{*}{ Animals species } & \multirow{2}{*}{ Number } & \multicolumn{2}{c}{ Animals showing signs of BEF } \\
\cline { 3 - 4 } & & Number & Percentage \\
\hline Cattle & 1248 & 397 & 31.81 \\
Buffaloes & 537 & 35 & 6.52 \\
Total number & 1785 & 432 & 24.20 \\
\hline
\end{tabular}

Table (2): Severity of clinical reaction in animals with bovine ephemeral fever.

\begin{tabular}{|c|c|c|c|}
\hline Animal species & Severity & \multicolumn{2}{|c|}{ Distinguishing signs } \\
\hline \multirow[b]{2}{*}{ Cattle } & Mild & \multicolumn{2}{|c|}{$\begin{array}{l}\text { Transient fever, inappetences, excess salivation, slight, shivering and } \\
\text { stiffens and lameness. This form was most commonly in young } \\
\text { calves, unfattened bull and lean dry non-pregnant cows. }\end{array}$} \\
\hline & Severe & \multicolumn{2}{|c|}{$\begin{array}{l}\text { Sudden onset of high fevers depression, anorexia, salivation } \\
\text { shivering, stiffness, lameness and some time recumbence. This form } \\
\text { was most common in fattened calves, mature heavy bull and cows at } \\
\text { last stage of pregnance and high - producing dairy cows }\end{array}$} \\
\hline Buffaloes & Mild & \multicolumn{2}{|c|}{$\begin{array}{l}\text { Transient fever, inappetence, slight salivation, stiffness and drop in } \\
\text { milk yield with disappearance of all these signs within } 12-36 \mathrm{~h} .\end{array}$} \\
\hline \multicolumn{2}{|c|}{ Signs } & Number & Percentage incidence \\
\hline Fever & & 397 & 100 \\
\hline Anorexia & & 381 & 95.97 \\
\hline Salivation & & 321 & 80.86 \\
\hline Nasal \& eye disch & & 198 & 49.87 \\
\hline Shivering & & 312 & 78.59 \\
\hline Stiffens & & 365 & 91.94 \\
\hline Lameness & & 331 & 83.37 \\
\hline Recumbence & & 282 & 71.03 \\
\hline Oedema & & 107 & 26.95 \\
\hline Enlargement of ly & des & 95 & 23.93 \\
\hline Drop of milk proc & & $85^{*}$ & 84.16 \\
\hline Mastitis & & $2^{*}$ & 1.58 \\
\hline Abortion & & $1 * *$ & 0.99 \\
\hline
\end{tabular}

* Among 101 dairy cows

* * Among 127 pregnant cows. 
Table (4): Hematological examination and biochemical analysis of some elements of 6 diseased cattle with BEF.

\begin{tabular}{lcc}
\hline \multicolumn{1}{c}{ Items } & Diseased animals & Three weeks post - recovery \\
\hline Total RBCS (×0 / UL) & $3.16 \pm 0.35^{*}$ & $4.62 \pm 0.18$ \\
PCV \% & $21.41 \pm 0.5^{*}$ & $26.33 \pm 021$. \\
Hb $(\mathbf{g m} / \mathbf{d l})$ & $6.70 \pm 0.11^{*}$ & $8.9 \pm 0.13$ \\
Total W.B.Cs. $\left(\mathbf{x 1 0 ^ { 3 }} / \mathbf{U L}\right)$ & $7.36 \pm 0.98$ & $7.57 \pm 0.8$ \\
Neutrophil \% & $52.2 \pm 1.35^{*}$ & $30.5 \pm 1.6$ \\
Lymphocyte \% & $37.9 \pm 0.37^{*}$ & $58.4 \pm 1.91$ \\
Basophil \% & $1.1 \pm 0.11$ & $0.9 \pm 0.1$ \\
Esionophil \% & $3.6 \pm 0.75$ & $5.3 \pm 0.13$ \\
Monocyte \% & $5.2 \pm 0.41$ & $4.9 \pm 0.55$ \\
Fibrinogen mg/dl & $299 \pm 18^{*}$ & $189 \pm 11$ \\
Calcium mg/dl & $7.05 \pm 0.03^{*}$ & $8.98 \pm 0.06$ \\
Phosphorus mg/dl & $2.91 \pm 0.6^{*}$ & $3.81 \pm 0.19$ \\
\hline
\end{tabular}

Values were expressed as mean \pm S.E.

* Means were highly significant at $<0.005$

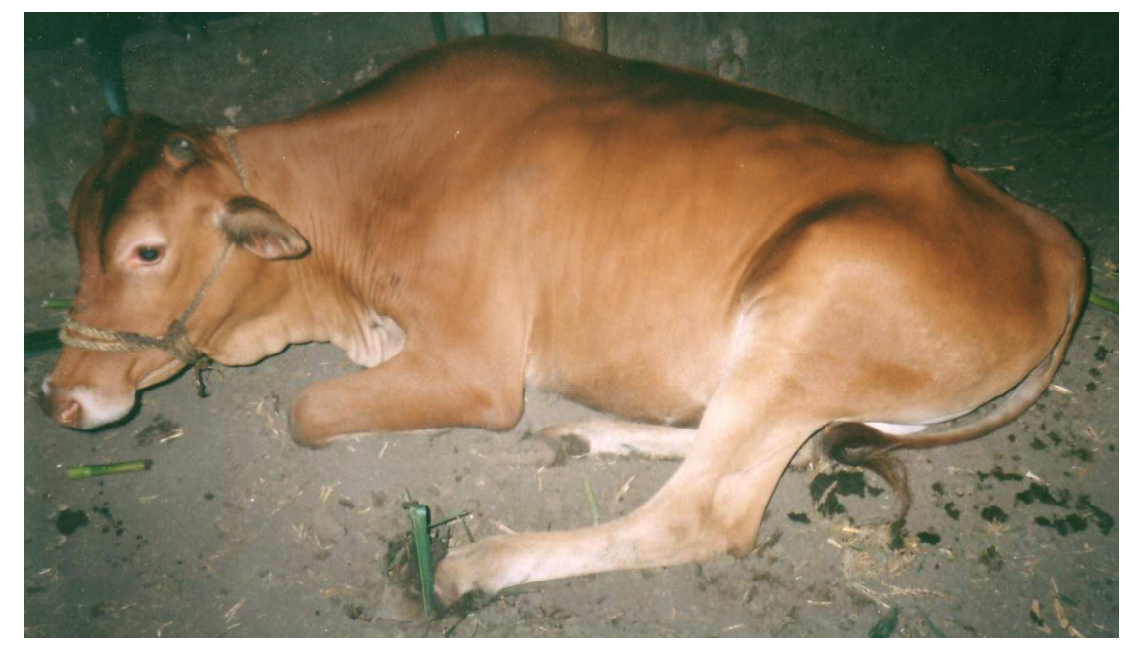

Fig. (1): Illustrates diseased cattle with BEF showing depression and recumbence.

position or a short period of recumbency after which recovery may be spontaneous, unexpected and sudden within 2-3 days of the firstly observed clinical signs (Table. 2). Sudden and massive drop of milk yield as wall as a abortion in last stages of pregnancy were recorded. The observed clinical signs in this study simulated that described by (Burgess, 1971 and Kahrs, 
2001). Moreover, the nature and severity of the clinical signs among the affected cattle were varying according to their ages, body condition, and reproduction and production status. Young calves, unfattened bulls and dry lean non pregnant cows showed only mild signs while fattened calves, mature heavy bulls and highly producing dairy cows and cows at late stages of pregnancy were affected more severely and signs persisted longer. Similar finding of the disease were also recorded by (Nadi and Negi, 1999 and Kahrs, 2001). The frequency of clinical signs of the disease among the affected cattle showed that, the fever, inappetence, stiffness, lameness and recumbency were the most prominent signs (Table. 3). Similar observation was also recorded by (Burgess, 1971). On the other hand, deaths and other complications such as pneumonia and subcutaneous emphysema were not recorded in this study. This finding may be due to the low virulence of the virus and immune status of infected animals.

In Buffaloes, the observed clinical signs were mild in the form of transient fever (39$39.9^{\circ} \mathrm{C}$ ), inappetance, stiffness, slight salivation, sometimes shivering in muscles and drop of milk yield with rapid recovery within 12-36 hours. These findings were coincided with those reported by (Davies et al., 1975; Bai et al., 1989 and Daoud et al., 2005) who recorded that, buffaloes are less susceptible to bovine ephemeral fever and considered as additional host .

Serological examination of serum samples collected from diseases animals showing signs of bovine ephemeral fever using virus neutralization test, showed that neutralizing antibody titers for bovine ephemeral fever virus ranged from 4-32. The antibody titers were absent or low in samples collected during the early stage of the disease followed by rising of titers in samples collected after 21 days from the appearance of clinical signs. This confirms the occurrence of the disease among examined animals (Burgess, 1974).

Bovine ephemeral fever in cattle is accompanied by wide range of hematological and biochemical changes which are characteristic of an inflammatory response (Kahrs, 2001). In this investigation, the erythrogram of diseased cattle with BEF showed anemia represented by significant decrease in RBCS, $\mathrm{PCV} \%$ and $\mathrm{Hb}$ content. The leukogram showed basic and early diagnostic feature of the disease. There was neutrophilia and lymphopenia with normal leukocytic count. Also, there was a rise in plasma fibronogen and drop in calcium and phosphorus values. All of these parameters were more or less improved three weeks post-recovery. These findings coincided with those reported by (Uren et al., 1992; Fenner et al., 1993; St. George et al., 1995; Nandi and Negi, 1999; Hassan, 2000 and Attia and Selim, 2000). Such changes could be probably correlated with the viremic stages of the disease.

Recovery from bovine ephemeral fever is usually spontaneous. However, symptomatic treatment has been found to be beneficial to reverse of numbers of symptoms, rapid recovery and to overcome the downer position caused by the infection with bovine ephemeral fever virus (St. George, 1997). In this investigation, good nursing care and early treatment for severe cases with non-steroid anti-inflammatory drug (ButaFenil) or administration of calcium borogluconate (Ca-D-Mag) of lame or recumbent animals lead to rapid and prompt recovery. This finding agreed with the previous report of (Uren et al., 1989; Fenwick and Daniel, 1997 and Hassan, 2000).

\section{References}

Attia, H. and Selim, H. (2000): Clinical, hematological and biochemical studies on bovine ephemeral fever. Proceeding of the 9th Sci. Cong.2000 Fac. Vet. Med. Assiut Univ., Egypt, 292-300.

Bai, W. B.; Zhang, Z. G. and Jiang, C. L. (1989): Clinical and pathological responses of water buffalo (Bubalus. bubalis) to experimental infection with bovine ephemeral fever virus - Chinese strain. Aust. Vet. J., 66 
(11): $373-347$.

Banoub, S. M. (1994): "Ephemeral fever (three days sickness) in closed milking cow farm at Sharquia". $6^{\text {th }}$ Sci. Cong., Fac. Vet. Med., Assiut, Egypt. 558-563.

St. George, T.D. (1997): Effective treatment of bovine ephemeral fever. Aust. Vet. J. 75: 221-223.

Burgess, G. W. (1971): Bovine ephemeral fever: A review. Vet. Bull., 41 (11): 887-895.

Burgess, G. W. (1974): A micro - titer serum neutralization test for bovine ephemeral fever virus. Aust. J. Exp. Bio. Med. Sci., 52(5): 851-855.

Cabery, L. and Lee, H. (1966): Serum neutralization tests for BVD and IBR viruses employing established tissue culture cell lines. Proc. 69th Annual Meet. U.S. Livestock Saint. Ass. 501.

Coles, E. H. (1986): Clin. Path. $2^{\text {nd }}$ ed. W. B. Sannders Company، Philadelphia, London, Toronto.

Daoud, A. M.; Younis, E. E.; El-Sawalhy, A. A; Sayed, A. M. Z. and Khodier, M. H. (2005): Some studies on bovine ephemeral fever in buffaloes. $4^{\text {th }}$ Int. Sci. Conf. Mansoura, 5-6 April 2005. pp. 687-701.

Davies, F. G.; Shaw, T. and Ochieng, P. (1975): Observations on the epidemiology of ephemeral fever in Kenya. J. Hyg., Cambridge. 75: 231-235.

Fenner, F. J.; Gibbs, E. P. L.; Murphy, F. A; Rott, R.; Studert, M. J. and White, D. O. (1993): Bovine ephemeral fever. Inter. Virology, $2^{\text {nd }}$ ed. Academic Press. California. 504-505.

Fenwick, D. C. and Daniel, R. C. (1997): Evaluation of the effect of Ketoprofen on experimentally induced ephemeral fever in dairy heifers. Aust. Vet. J., 75 (3): 221223.

Hassan, H. Y. (2000): An outbreak of bovine ephemeral fever in Egypt during 2000. II - Clinico - Chemical and hematological alterations before and after symptomatic treatment trials. $9^{\text {th }}$ Sci. Cong. 2000, Fac. of Vet. Med., Assuit Uni., Egypt. Pp. 325-336.

Hassan, H. B.; El. Danaf, N. B.; Hafez, M. A. M.; Regab, A. M. and Fathia, M. M. C. (1991): Clinico diagnostic studies on bovine ephemeral fever with detection of its virus for the first time in Egypt. First Sci. Cong. Egyp. Soci. for Cattle Diseases, 1-3: 77-85.

Hill, H. M. W. and Schultz, K. (1977): Ataxia and paralysis associated with bovine ephemeral infection. Aust. Vet. J., 53:217-221.

Kahrs, R. F. (2001): Viral diseases of cattle. $2^{\text {nd }}$ ed. Iowa state University Press /Ames.

Nadi, S. and Negi, B. S. (1999): "Bovine ephemeral fever:
A review". Comp. Immun. Microbiol. Infect. Dis. 22:81-91. Rabagliati, D. S. (1924): Three days fever or stiff sickness in cattle. Vet. Rec., 4:503-505.

Rosenberger, G. (1990): Die Klinische Untersuchung des Rindes. 3, Auflage herausgegben von Dirksen, G. Grunder, H. D. and Sotober, M .Verlag paul parey Berlin and Humburg.

Soad, M.; Taha, M. M.; Samir, S. S. and Daoud, A. M. (2001): Isolation and identification of BEF virus in Egypt. Beni-Seuef Vet. Med. J. XI: 609-617

Selvin, S. (1996): "Statistically analysis of epidemiologic dataa." $2^{\text {nd }}$ ed. Pp .44-78 Oxford Univ. press, New York, London.

Sharma, L. K. (1992): A report on bovine ephemeral fever in cattle. Ind. Vet. J., $59: 544-546$.

Singh, K. V.; Osman, O.; El-Cicy, L. E.; Ata, F. A. and Baz, T. I. (1967): Response of water buffaloes to experimental injection with rinderpest virus. Cornell. Vet. 57: 638-648.

St. George, T. D. (1997): Effective treatment of bovine ephemeral fever. Aust. Vet. J., 75: 221-223.

St. George, T. D. (1998): Bovine ephemeral fever. In Foreign Animal Diseases, edited by WWUS. Anim. Hlth. Assoc. Pp. 118-128.

St. George, T. D.; Murphy, G. M.; Burren, B. and Uren, M. F. (1995): "Studies on the Pathogenesis of bovine ephemeral fever. IV: A comparison with the inflammatory events in milk fever of cattle". Vet. Microbiol., 46 (1:3):131-142.

Theodoridis, A.; Giesecke, W. H. and Du Toit, I. J. (1973): Effects of ephemeral fever on milk production and reproduction of dairy cattle. Ondersteport J. Vet. Res., 40 (3): 83-91.

Tietz, N. (1986): "Fundam of clin. Chem.: W.B. Saunder Co., Philadelphia U.S.A.

Uren, M. F.; St. Georg, T. D. and Murphy, G. M. (1992): "Studies on the pathogensis of bovine ephemeral fever in experimental cattle." Vet. Microbiol., 30:297-307.

Uren, M. F.; St. Georg, T. D. and Zakrzewshi, H. (1989): "The affect of anti-inflamatory agents on the clinical expression of bovine ephemeral fever". Vet. Microbiol., 19: 99-111.

Zaghawa, A., Akela, M. A.; Khader, A. M. and Hassan, H. Y. (2000): An outbreak of bovine ephemeral fever in Egypt during 2000. Clinical and epidemiological investigation. $9^{\text {th }}$ Sci. Cong. 2000 Fac. Vet. Med. Assiut Univ., Egypt. pp. 346-353. 